

\title{
SEJARAH DAN PERKEMBANGAN PENDIDIKAN ISLAM
}

\author{
BEKTI TAUFIQ ARI NUGROHO, M.Pd.I \\ MOHAMMAD DZAWINNUHA S.Hum. M.Pd
}

\section{Pengantar :}

Prof. Dr. H. Mansur, M.Ag

(Guru Besar dan Dekan FTIK IAIN Salatiga)

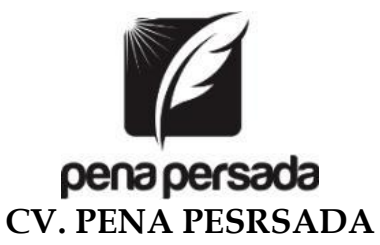




\title{
SEJARAH DAN PERKEMBANGAN PENDIDIKAN ISLAM
}

\section{Penulis :}

Bekti Taufiq Ari Nugroho, M.Pd.I

Mohammad Dzawinnuha S.Hum. M.Pd

\section{Editor :}

Mohammad Dzawinnuha S.Hum. M.Pd

\section{ISBN : 978-623-6837-38-2}

\section{Design Cover :}

Retnani Nur Briliant

\author{
Layout : \\ Hasnah Aulia
}

Penerbit CV. Pena Persada

Redaksi :

Jl. Gerilya No. 292 Purwokerto Selatan, Kab. Banyumas Jawa

Tengah

Email : penerbit.penapersada@gmail.com

Website : penapersada.com

Phone : (0281) 7771388

Anggota IKAPI

All right reserved

Cetakan pertama : 2020

Hak cipta dilindungi oleh undang-undang.

Dilarang memperbanyak karya tulis ini dalam bentuk dan cara apapun tanpa ijin penerbit 


\section{KATA PENGANTAR}

Pendidikan Islam mengikuti masa dan dinamika perkembangan kaum muslim. Di mana ada komunitas muslim, maka terdapat tingkat aktifitas pendidikan Islam yang dilaksanakan sesuai dengan situasi dan kondisi. Sejarah yang membahas peristiwa masa lalu (event the past), jangan dianggap remeh dan dibiarkan lewat seiring dengan berlalunya waktu, sebab begitu besar makna sejarah bagi kehidupan umat manusia. Belajarlah dari sejarah, demikian kata-kata mutiara yang dapat mengingatkan makna sejarah itu. Bahkan Bung Karno sebagai Presiden RI yang pertama, telah menitipkan sesuatu yang sangat berharga berupa "JAS MERAH", sebagai akronim dari "Jangan Sampai Melupakan Sejarah". Sejarah memang sangat bermanfaat bagi kehidupan umat manusia, karena sejarah menyimpan atau mengandung kekuatan yang dapat menimbulkan dinamisasi dan melahirkan nilai-nilai baru bagi perkembangan kehidupan manusia. Dapat dikatakan begitu pentingnya sejarah termasuk sejarah pendidikan Islam itu.

Dengan mengkaji sejarah pendidikan Islam akan bisa memperoleh informasi tentang pelaksanaan pendidikan Islam dari zaman Rasulullah sampai sekarang, mulai dari pertumbuhan, perkembangan, kemajuan, kemunduran, dan kebangkitan kembali tentang pendidikan Islam. Dari sejarah dapat diketahui segala sesuatu yang terjadi dalam penyelenggaraan pendidikan Islam dengan segala ide, konsep, institusi, sistem dan operasionalnya yang terjadi dari waktu ke waktu.

Dari sejarah, dapat dijadikan sebagai dasar berpijak untuk mengembangkan pendidikan di masa sekarang, dapat mengambil yang baik dan membuang yang tidak baik termasuk kesalahankesalahan pada masa lalu, al muhafadzatu ala al-qadim al-salih wa alakhodzu ala al-jadid al aslah. Dari sejarah dapat diambil hikmah dari apa yang telah terjadi pada masa lalu (event the past) dalam rangka menentukan langkah di masa depan.

Buku yang ditulis oleh Bekti Taufiq Ari Nugroho, M.Pd.I. dan Mohammad Dzawinnuha S.Hum. M.Pd. ini membahas tentang sejarah dan perkembangan pendidikan Islam sejak zaman 
Rasulullah sampai era globalisasi. Oleh karena itu buku ini tepat dibaca oleh mahasiswa Fakultas Tarbiyah dan Ilmu Keguruan dan siapa saja yang berminat mengetahui serta mendalami sejarah perkembangan pendidikan Islam. Dalam kesempatan ini, saya selaku Guru Besar dan Dekan FTIK IAIN Salatiga menyambut dengan senang hati dan mendukung atas terbitnya buku ini. Mudah-mudahan bermanfaat dan mendapatkan ridlo Allah swt. Amin.

Salatiga, 1 September 2020

Prof. Dr. H. Mansur, M.Ag.

Guru Besar dan Dekan FTIK IAIN Salatiga 


\section{PRAKATA PENULIS \\ Bekti Taufiq Ari Nugroho, M.Pd.I.}

Sejarah pendidikan Islam pada hakikatnya tidak lepas dari sejarah Islam. Sejarah Islam merupakan sejarah suatu bangsa yang tidak lepas dari pendidikan Islamnya. Sejarah pendidikan Islam adalah cerita yang tersusun dan sistematis dari satu periode ke periode berikutnya, dari usaha dalam mencerdaskan dirinya dan masyarakat sekitar, mengembangkan potensinya, terutama mewariskan kecerdasan dan potensi tersebut kepada generasi selanjutnya, untuk melestarikan tradisi budayanya sesuai nilai normatif Islam yaitu Al-Qur'an dan Al-Hadits. Pandangan dan sikap keilmuan di zaman Nabi Muhammad yang memposisikan ilmu secara pararel tersebut itu menyebabkan explorasi terhadap ilmu selain "ilmu agama" sudah mulai dilakukan meskipun dalam kadar yang sangat sederhana.

Semenanjung Arab secara geografis merupakan bagian Benua Asia di sebelah barat daya yang dibatasi oleh Laut Merah di sebelah barat, Laut Arab dan Samudra Hindia di sebelah selatan, Teluk Oman dan Teluk Arab di sebelah tirnur, Daratan Syam di sebelah timur, serta Teluk Persia di sebelah timur laut.

Sejarah Arab sebelum kedatangan agama Islam tidak banyak diketahui. Sebab, kawasan Arab merupakan tempat kelahiran Islam, dan bangsa Arab adalah masyarakat pertama yang menjumpai risalah agama Islam. Keadaan yang demikian menjadikan keadaan yang hanya mengandalkan hawa nafsunya, sehingga dikatakan bahwa mereka tidak memiliki dasar atas kebenaran yang yang hakiki. Ilmu di masa Rasul dan khalifah adalah sesuatu yang sangat berharga. Mereka juga membanggabanggakan nasab, golongan, harta, dan keturunan yang banyak. Untuk menguraikannya secara lebih mendetail, berikut dijelaskan keadaan Arab sebelum Islam dan aspek geografi, sosial, ekonomi, politik, budaya, dan agamanya.

Terjadinya era globalisasi memberi dampak ganda, dampak yang menguntungkan dan dampak yang merugikan. Kondisi Sosiokultural Pra-Islam Fase Awal Islam Keadaan sosial masyarakat pada masa Nabi Muhammad adalah masyarakat yang 
menyembah berhala, mereka tidak mempunyai dasar beragama. Periode Makkah, Nabi Muhammad lebih menitikberatkan pembinaan moral dan akhlak serta tauhid kepada masyarakat Arab yang bermukim di Makkah dan pada peroide di Madinah Nabi Muhammad SAW melakukan pembinaan di bidang sosial. Globalisasi sebagai sebuah proses mempunyai sejarah yang panjang. Sebab, situasi saat itu belum memungkinkan penulisan sejarah, yakni kehidupan mereka yang cenderung nomaden dan banyak terlibat dalam peperangan di antara mereka. 


\section{PRAKATA PENULIS DAN EDITOR Mohammad Dzawinnuha S.Hum. M.Pd}

Syukur Alhamdulillah, segala puji penulis panjatkan kehadirat Allah SWT atas rahmat, taufik dan hidayahnya buku ini selesai disusun. Buku ini disusun untuk membantu para mahasiswa dalam mempelajari Sejarah Pendidikan Islam dari masa Pra Islam hingga Islam modern.

Di era pandemi yang melanda masyarakat global dunia, mengakibatkan kita semua mengalami dampak dan hidayah atas musibah tersebut. Termasuk buku ini, merupakan hasil dari tulisan karena karantina mandiri yang dilakukan oleh semua kalangan akademisi termasuk pengajar. Dalam mata kuliah sejarah pendidikan Islam khususnya, mahasiswa mengalami kecenderungan minim akan referensi. Sehingga bagi kalangan pengajar memutar otak supaya bagaimana mahasiswa dalam kondisi yang tidak keluar dari kewajibannya.

Terlepas dari itu semua, Tulisan ini dimaksudkan untuk menambah hasil pengetahuan mahasiswa dalam mempelajari materi mata kuliah sejarah pendidikan Islam. Dengan demikian, penulis sadar bahwa tullisan ini bisa dimanfaatkan oleh kalangan yang lebih luas tidak hanya mahasiswa tetapi juga akademisi lainnya dan umum. Bahan bacaan ini tidak terlepas dari silabisilabi yang ada di materi mata kuliah sejarah pendidikan Islam. Uraian dalam buku ini bersifat ringkasan-ringkasan dan garisgaris besar saja dalam sebuah kajian-kajian dan penelitianpenelitian. bagi para pembaca dapat merujuk kepada literature yang sudah kami sebutkan dalam buku ini agar lebih mendalam dan pembahasan yang lebih luas.

Penulis menyadari apabila dalam penyusunan buku ini terdapat kekurangan, tetapi penulis meyakini sepenuhnya bahwa sekecil apapun buku ini tetap memberikan manfaat. Untuk itu, saran dan masukan dari para pembaca guna memperbaiki buku ini sangat diharapkan. Akhirnya, kepada semua pihak yang telah turut membantu penulis dalam rangka mewujudkan buku ini penulis ucapkan terimakasih. Semoga buku ini menjadi amal ibadah yang di-ridhai-Nya. Amiin. 


\section{SINOPSIS}

Sejarah Arab sebelum kedatangan agama Islam tidak banyak diketahui. Semenanjung Arab secara geografis merupakan bagian Benua Asia di sebelah barat daya yang dibatasi oleh Laut Merah di sebelah barat, Laut Arab dan Samudra Hindia di sebelah selatan, Teluk Oman dan Teluk Arab di sebelah tirnur, Daratan Syam di sebelah timur, serta Teluk Persia di sebelah timur laut. Sebab, kawasan Arab merupakan tempat kelahiran Islam, dan bangsa Arab adalah masyarakat pertama yang menjumpai risalah agama Islam. Tanah yang subur biasanya berada di daerah yang mendapatkan curah hujan tinggi.

Kata "Arab" berarti padang sahara berpasir. Sebab, situasi saat itu belum memungkinkan penulisan sejarah, yakni kehidupan mereka yang cenderung nomaden dan banyak terlibat dalam peperangan di antara mereka. Informasi yang terjangkau mengenai permasalahan ini diperoleh dan waktu sekitar 150 tahun sebelum kedatangan Islam. Luas kawasan ini sekitar $3.237 .500 \mathrm{~km} 2$ yang sekarang meliputi berbagai negara. Dalam konteks ini, pemakaian istilah Jazirah Arab yang sering dijumpai dalam berbagai referensi sejarah hendaknya dimaklumi dengan tetap menunjukkan istilah yang benar sesuai fakta geogralìsnya. Untuk menguraikannya secara lebih mendetail, berikut dijelaskan keadaan Arab sebelum Islam dan aspek geografi, sosial, ekonomi, politik, budaya, dan agamanya.

Nabi Muhammad di utus untuk semua umat di muka bumi. Ilmu di masa Rasul dan khalifah adalah sesuatu yang sangat berharga. Periode Makkah, Nabi Muhammad lebih menitikberatkan pembinaan moral dan akhlak serta tauhid kepada masyarakat Arab yang bermukim di Makkah dan pada peroide di Madinah Nabi Muhammad SAW melakukan pembinaan di bidang sosial. Mereka juga membangga-banggakan nasab, golongan, harta, dan keturunan yang banyak.

Kondisi Sosiokultural Pra-Islam Fase Awal Islam Keadaan sosial masyarakat pada masa Nabi Muhammad adalah masyarakat yang menyembah berhala, mereka tidak mempunyai dasar beragama. Keadaan yang demikian menjadikan keadaan yang viii 
hanya mengandalkan hawa nafsunya, sehingga dikatakan bahwa mereka tidak memiliki dasar atas kebenaran yang yang hakiki. Pada masa itu masyarakat masih kuat dengan ajaran agama yang dianutnya dan menjadikan patung-patung (berhala) sebagai Tuhan mereka.

Ajaran yang sangat kuat dan kakek-nenek moyang mereka menjadikan Nabí Muhammad sangat sulit untuk menyiarkan agama Islam kepada masyarakat arab pada saat itu, sehingga banyak yang menentang dan pada yang mengikutinya. Tujuan maktab yang masih bertahan di banyak bagian dunia Islam, yaitu memperkenalkan remaja dengan ilmu membaca, menulis, dan lebih khusus dengan prinsip-prinsip agama.

Bentuk peradaban yang paling besar dan luar biasa dan merupakan satu kerja besar yang dilakukan pada masa pemerintahan Abu Bakar adalah penghimpunan Al-Quran. Selain itu, peradaban Islam yang terjadi pada praktik pemerintahan $\mathrm{Abu}$ Bakar terbagi beberapa tahapan, yakni Dalam bidang pranata sosial ekonomi dan mengenai suksesi kepemimpinan.

Peradaban yang paling signifikan pada masa Umar, selain pola administratif pemerintahan, peperangan, dan sebagainya adalah pedoman dalam peradilan. Karya besar monumental khalifah Utsman adalah membukukan mushaf Al-Quran. Pada masa pemerintahan Khalifah Ali terjadi peristiwa tahkim. Yakni, konflik politik antara Ali ibn Abi thalib dengan Muawiyah.

Saat situasi politik, dinasti Umayyah berdiri pada tahun 41 $\mathrm{H}$ dan berakhir pada tahun132 $\mathrm{H}$ dipimpin oleh Muawiyah bin Abi Sofyan membuat Islam berkembang hingga Eropa dan Afrika. Para ahli sejarah umumnya mencatat, bahwa proses berdirinya kekhalifahan Bani Umayyah diperoleh melalui kekerasan, diplomasi, dan tipu daya, tidak melalui pemilihan yang demokratis berdasarkan suara terbanyak.

Dalam situasi sosial, Muawiyah mendirikan dinas pos dan tempat-tempat tertentu dengan menyediakan kuda yang lengkap dengan peralatannya di sepanjang jalan. Selain itu, Bani Umayyah mengganti mata uang daerah yang dikuasainya dengan mata uang 
baru dan memberlakukan penggunaan bahasa Arab di semua daerah kekuasaan Bani Umayyah.

Dibidang keagamaan, pada masa Bani Umayyah ditandai dengan munculnya berbagai aliran keagamaan yang bercorak politik ideologis. Mereka itu antara lain golongan Syi'ah, Khawarij dengan berbagai sektenya: Azariqah, Najdat Aziriyah, Ibadiyah, Ajaridah dan Shafariyah, golongan Mu'tazilah, Maturidiyah, Asy'ariyah, Qadariyah, dan Jabariyah.

Kondisi pendidikan di masa Bani Umayyah mengacu pada kemampuan ilmu agama dan ilmu umum supaya Dinasti Umayyah dapat unggul dalam segala bidang. Dalam kurikulum yang diusung dari bidang agama, sejarah, bahasa, dan filsafat menunjukkan seriusnya dalam peningkatan ilmu agama dan umum. Lembaga-lembaga yang dibuat oleh Dinasti Umayyah antara lain: Istana, Badiah, al-Bimaritsan, dan Perpustakaan.

Pengelolaan pendidikan dapat diartikan sebagai kegiatan merencanakan (planning), mengorganisasikan (organizing), melaksanakan (actualing), mengawasi (controling), membina (supervising), dan menilai (evaluating) hal-hal yang berkaitan dengan seluruh aspek pendidikan: kurikulum, proses belajar mengajar, hasil pembelajaran, kinerja para guru dan staf, pelayanan administrasi pendidikan, dan respon masyarakat.

Setelah khilafah Abbasiyah berdiri, dinasti Bani Abbasiyah tetap mempertahankan persekutuan itu. Dalam memperkuat kekuatan, khilafah Abbasiyah Bani Abbasiyah juga bersekutu dengan orang-orang Persia. Sejarah Pendidikan Islam dimulai dari masa Nabi Muhammad, kemudian dilanjutkan di bawah pimpinan para khalifah Nabi Muhammad, kemudian masa Bani Umayyah yang dilanjutkan oleh kekuasaan Bani Abbasiyah didalam kekuasaan Islam. Propaganda gerakan Bani Abbasiyah dibedakan dalam dua bentuk, yaitu propaganda yang dilakukan secara rahasia dan terang-terangan.

Khilafah Bani Abbas inilah yang menjadi kekuatan baru Islam di dunia dengan berbagai perkembangan yang sangat pesat, termasuk didalamnya dalam dunia ilmu pengetahuan dan pendidikan. Pada masa bani Abbasiyah merupakan zaman 
keemasan Islam (abad 9-12 M), yaitu berbagai kemajuan diciptakan umat Islam untuk kemajuan peradaban.

Munculnya gerakan Bani Abbas yang sukses menggulingkan kekuasaan Dinasti bani Umayyah itu disebabkan oleh dua faktor, yaitu faktor eksternal dan faktor internal. Dengan terbunuhnya Marwan Ibn Muhammad (Marwan II) dan jatuhnya Damaskus sebagai pusat pemerintahan Dinasti Bani Umayyah, maka berakhirlah sudah riwayat kekuasaan Dinasti Bani Umayyah. Dalam propaganda yang secara rahasia itu mereka telah melakukan persiapan yang benar-benar matang baik secara pemikiran (mental) maupun situasi dan kondisi.

Kekuasaan Bani Abbasiyah terbagi menjadi beberapa periode, yang dari semua periode tersebut puncak kejayaan bani Abbasiyah berada ditangan khalifah Harun Ar-rasyid dan putra al-Makmun, meskipun pada kenyataannya semua khalifah Bani Abbasiyah memiliki peran yang sangat penting dalam perkembangan pendidikan. Majlis al-Tadris, Majlis al-Munazarah, Majlis al-Muzakarah, Majlis al-Syu'ara, Majlis al-Adab, Majlis alFatwa, dan Masjid.

Nama Ustman itulah yang diambil sebagai nama untuk kerajaan Turki Ustmani. Bangsa Turki memiliki peranan yang sangat penting dalam perkembangan peradaban Islam. Dinasti Turki Ustmani merupakan kekhalifaan yang cukup besar dalam Islam dan memiliki pengaruh cukup signifikan dalam perkembangan wilayah Islam di Asia, Afrika, dan Eropa. Kerajaan Turki Ustmani didirikan oleh suku bangsa pengembara yang berasal dari wilayah Asia Tengah, yang termasuk suku Kayi. Erthogrol mempunyai seorang putra yang bernama Usman yang diperkirakan lahir tahun 1258.

Beberapa peninggalan budaya dan peradaban Islam banyak yang hancur akibat serangan bangsa Mongol terhadap pusat peradaban Islam di Bagdad. Sulaiman ingin pindah lagi ke wilayah Syam setelah ancaman Mongol reda. Dalam perkembangan kekhalifahan, Turki Usmani mengalami kemajuan yang luar biasa, mulai dari kehidupan keagamaan, ekonomi, hukum, militer, politik dan bahkan kemajuan pendidikan. Ulama 
memiliki kedudukan tinggi dalam kehidupan negara, masyarakat, serta pada masa Turki ustmani tarekat sangat berkembang pesat dan mempunyai pengaruh yang besar terhadap kekuasaan. Turki Ustmani dibawah kekuasaan khalifah Sultan Muhammad Al-Fatih berhasil berada dipuncak kejayaan dan satu-satunya kekhalifahan yang berhasil menaklukkan Konstantinopel yang menjadi ibu kota Kerajaan Romawi.

Pendidikan pada masa Islam Andalusia dapat berkembang pesat dengan corak pendidikan yang diterapkan, metode yang digunakan, lembaga pendidikan yang berkembang dan kemajuankemajuan pendidikan pada masa Islam di Andalusia. Kebijakan yang membawa kemajuan dalam ilmu pengetahuan, Kebudayaan, dan peradaban terjadi pula kemajuan dalam bidang pendidikan.

Dari satu sisi pendidikan mendorong kemajuan dalam bidang ilmu pengetahuan, kebudayaan, dan peradaban, di sisi lain penerapan ilmu pengetahuan, kebudayaan dan peradaban mampu memberikan pengaruh terhadap kemajuan pendidikan. Hal ini terjadi Karena antara pendidikan dan perkembangan ilmu pengetahuan memiliki hubungan fungsional.

Pada Masa itu Islam berada dalam keemasan, dimana Andalusia/Spanyol merupakan Pusat peradaban Islam yang sangat penting. Sehingga sejarah pendidikan Islam pada Masa kekuasan Umayyah di Andalusia meliputi kondisi sosial singkat Umat di Andalusia, Corak pendidikan Islam yang diterapkan, kemajuan pendidikan, lembaga-lembaga yang berkembang, hasil pendidikan dan tantangan. Eropa pada waktu itu hidup dalam masa-masa kebodohan dan keterbelakangan yang luar biasa, yang biasa disebut dengan masa kegelapan (Dark Age).

Andalusia yang dikenal dengan negara Spanyol ini merupakan berada di bawah kerajaan Romawi sebelum Islam masuk. Bahkan Spanyol atau Andalusia ini mampu menyaingi Islam yang berpusat di Baghdad di Timur, seperti halnya orangorang Eropa Kristen banyak tertarik belajar diperguruanperguruan tinggi Islam di Andalusia. Bangsa Romawi dapat menguasai simenanjung itu pada tahun $133 \mathrm{M}$. Di masa pemerintahan mereka ini, masuk pula sejumlah besar orang-orang 
Yahudi. Pada masa itu kebudayaan Islam di negeri itu mencapai puncak perkembangannya.

Masuknya Islam di Andalusia pada abad ke (705-715) tidak terlepas dari peran seorang Khalifah Al-Walid yang sebelumnya mampu menguasai Afrika Utara. Sedangkan kekuasaan Islam di Andalusia pertama kali hingga Islam runtuh memainkan peranan yang sangat besar, baik itu politik, ekonomi, budaya, dan bahkan pendidikan, hingga berlangsung lebih dari tujuh setengah abad. Kemajuan peradaban dan kebudayaan Islam pada masa dinasti Umayyah membuat ekspansi besar-besaran sampai ke daratan Eropa, salah satunya yaitu Andalusia, sekarang disebut sebagai negara Spanyol.

Daulah yang didirikan oleh Ubaidillah Al-Mahdi ini berpusat di Afrika Utara yaitu Kairawan. Tidak sampai disitu, khalifah Fatimiyah mampu mendirikan sejumlah sekolah dan perguruan tinggi, mendirikan perpustakaan umum serta lembaga ilmu pengetahuan. Menteri-menteri dibagi dalam dua kelompok yaitu kelompok militer dan kelompok sipil. Wilayah Afrika kecil, Tunisi dan Afrika Utara ketika itu beraada di bawah kekuasaan Aglabiyah. Baru setelah pemerintahan di pegang oleh Al-Aziz Billah mengubah fungsi masjid al-Azhar menjadi universitas.

Kekayaan dan kemakmuran dinasti Fatimiyah dan besarnya perhatian para khalifah merupakan faktor pendorong para ilmuan untuk berpindah ke Kairo. Dar al-Hikmah merupakan prakarsa terbesar untuk pengembangan ilmu pengetahuan yang didirikan oleh khalifah al-Hakim pada tahun 1005 M. Meskipun pada awalnya Dar al-Hikmah sebagai lembaga sarana penyebaran dan pengembangan ajaran Syi'ah Ismailiyah. Lulusan nilai pertama dapat bekerja sebagai pengajar untuk buku-buku tingkatan tinggi, nilai kedua untuk buku-buku tingkatan menengah, dan nilai ketiga untuk buku-buku tingkatan dasar.

Para khalifah yang berhasil menduduki suatu wilayah akan mengganti nama tempat tersebut dengan nama mereka misalkan, Ubaidillah al-Mahdi mendirikan kota al-Mahdiah di Tunisia, alMansur juga mendirikan kota al-Mansuriah, pada masa khalifah al-Mui'z mampu mendirikan kota al-Qahirah. Dalam 
perkembangannya, aliran Syi'ah sebagai aliran minoritas baik pada masa Dinasti Umayyah maupun Dinasti Abbasiyah, walaupun tatkala Dinasti Abbasiyah berjuang dan berhasil mengambil alih kekuasaan dari dinasti Umayyah yang pada saat itu mempunyai andil besar. Kekuasaan dinasti Fatimiyah membentang sampai ke Yaman hingga laut Atlantik, Asia kecil dan Mousul.

Gerakan Safawiyah selanjutnya bertambah luas dan berkembang sehingga yang pada mulanya hanya gerakan keagamaan saja berkembang dan bertambah menjadi gerakan politik. Pada periode Syah Abbas I merupakan puncak kejayaan Dinasti Syafawi. Kerajaan ini menyatakan sebagai penganut Syi'ah dan dijadikan sebagai Madzhab negara.

Kondisi Sosial Daulah Syafawiyah (1501-1736 M) berasal dari sebuah gerakan tarekat yang berdiri di Ardabil, sebuah kota di Azerbaijan, Iran. Dinasti Syafawi mempunyai perbedaan dari dua kerajaan besar Islam lainnya pada saat itu seperti kerajaan Turki Ustmani dan Mughal. Sejarah mencatat bahwa periode ini sebagai bangkitnya kembali kejayaan lama Persia. Kemajuan yang diraih tidakhanya kekuasaan, ekonomi dan ekspansi melainkan sikap Syah Abbas I terhadap pengembangan keilmuan dan pendidikan.

Tarekat ini diberi nama tarekat Safawiyah didirikan pada waktu yang hampir bersamaan dengan Daulah Turki Usmani di Asia Kecil. Nama Safawi ini terus dipertahankan sampai Tarekat Syafawiyah menjadi suatu gerakan politik dan menjadi sebuah Kekhalifahan yang disebut dinasti Syafawi. Dinasti Syafawi didirikan oleh Safi al-Din yang merupakan keturunan Imam Syi'ah yang keenam Musa Al-Kazhim yang mempunyai guru sekaligus mertua bernama Syekh Taju al-Din Ibrahim Zahiri (1216-1301 M) yang dikenal dengan panggilan Zahid al-Gilan. Pada masa dinasti Syafawi memiliki kemajuan yang luar biasa, ditandai dengan lahirnya sejumlah ilmuan-ilmuan, kemajuan seni arsitektur ditandai dengan berdirinya sejumlah bangunan megah, mesjid, 
sekolah, rumah sakit, jembatan dan lainnya sebagai bentuk berkembangnya ilmu pengetahuan.

Safi al-Din memilih sufi sebagai jalan hidupnya hidupnya serta menjadi seseorang yang ber prestasi dan tekun dalam kehidupan tasawuf. Kemunduran Kurang berkembangnya ilmu murni atau sains tetapi lebih banyak ilmu fiqih dan paham Syi'ah. Dalam Syiah Dua Belas ada dua golongan, yakni Akhbari dan Ushui. Sistem pendidikan pada masa dinasti Syafawi ini sebagai prototipe sistem pendidikan Syi' ah.

Pendidikan pada masa Mughol di India memiliki peranan yang sangat penting bagi kemajuan peradaban Islam terutama bidang pendidikan. Ayahnya Umar Mirza, merupakan seorang penguasa Ferghana. Bangsa Mongol mempunyai Nenek moyang bernama Alanja Khan, yang mempunyai putra kembar, Tatar dan Mongol. Timur Lenk pertama kali melakukan penyerangan ke India pada tahun 1398. Kemajuan-kemajuan peradaban dinasti Mughol dapat dilihat dari berbagai aspek, mulai dari sosial, politik, ekonomi dan bahkan ilmu pengetahuan atau bidang pendidikan.

Penaklukan India yang sesungguhnya baru di lakukan oleh Zahiruddin Muhammad Babur, salah seorang keturunan dari Timur Lenk. Hulagu merupakan salah seorang keturunan dari penguasa Mongol dari Jenghiz Khan yang terkenal dengan kekejaman dan petualangannya menghancurkan Islam dan kebudayaannya. Ibrahim Lodi beserta ribuan tentaranya terbunuh dalam pertempuran itu. Meskipun begitu, Timur Lenk tidak berambisi untuk menguasainya. Diantara keturunannya adalah Timur Lenk, keturunan Jengiz Khan yang telah masuk Islam dan pernah berkuasa di Asia Tengah pada abad ke-15.

Terutama terbentuknya dinasti mughol di India tidak terlepas dari kekuatan dan kegigihan bangsa Mongol untuk menegakkan Islam di daratan India. Dengan ditegakkannya pemerintahan Babur di kota Delhi, maka berdirilah kerajaan Mughal di India pada tahun 1526 M. Zahiruddin Muhammad Babur merupakan nama lengkap dari babur, pendiri pertama dinasti Mughol, Babur sendiri merupakan cucu Timur Lenk dari 
pihak ayah dan keturunan Jenghiz Khan dari pihak ibu. Namun setelah sampai ke anak cucunya mereka telah berubah, bukan lagi sebagai perusak tetapi justru sebagai pembangun Islam.

Kemunduran dan kemandekan keilmuan Islam dimulai dan abad ke-11 masehi dan seterusnya. Sebagian yang lain mengatakan ia bermula dari abad ke- 12 sampai abad ke-20. Pertanyaan yang tak kalah penting adalah apa faktor utama penyebab kemunduran pendidikan dan keilmuan Islam? Karena itu pula. Namun yang jelas, semua sarjana sepakat terjadinya kemunduran pendidikan Islam terjadi sejak abad ke- 16 sampai sekarang.

Perang Salib keempat (1204) menyerang Konstantinopel, sedang Perang Salib yang kelima. Yang benar dari ketiga pendapat di atas tentu tergantung dari sisi mana kita memahami makna dan kemunduran itu sendiri. Ada perbedaan pendapat tentang sejak kapan pendidikan Islam mulai mengalami kemunduran dan masa keemasannya. Ada yang mengatakan kemunduran Islam terjadi dari abad ke-15 atau 16 masehi mengingat masih banyaknya karya dan penemuan sarjana muslim di bidang sains dan teknologi dalam kurun waktu sebelum abad ke-16. Oleh karena itu, kemunduran atau kemiskinan suatu negara akan berdampak pada mundurnya keahlian.

Pendidikan Islam mengalami beberapa fase perkembangan seiring dengan perkembangan agama Islam itu sendiri. Eropa kemudian bangkit dan Islam mulai dijajah dan mengalami kemunduran.

Pendidikan Islam secara khusus tidak dapat disamakan dengan makna pendidikan secara umum. Penemuan-penemuan baru dibidang ilmu pengetahuan dan teknologi muncul di Eropa. Dengan demikian, dalam sebuah lembaga pendidikan pasti terjadi pertumbuhan dan perkembangan, dan ini sama halnya dengan pendidikan Islam. Puncak kejayaan pendidikan Islam dimulai dengan berkembang luasnya lembaga-lembaga pendidikan Islam dan madrasah-madrasah formal di berbagai pusat kebudayaan Islam.

Kemudian pendidikan Islam mengalami masa kebangkitan kembali yang dinamakan fase pembaharuan. Pada fase ini 
pendidikan Islam mulai naik kembali dengan beberapa tokoh pembaharu Islam. Setelah warisan filsafat dan ilmu pengetahuan Islam diterima oleh bangsa eropa dan umat Islam sudah tidak memperhatikannya lagi maka secara berangsur-angsur telah membangkitkan kekuatan di eropa dan menimbulkan kelemahan di kalangan umat Islam. Pendidikan Islam dikenal dan diyakini oleh penganut agama Islam sebagai suatu kegiatan pendidikan yang bersumber dari pokok ajaran Islam (al-Qur'an) dan al-Hadits sebagai penjelasnya.

Hal tersebut bergantung pada bagaimana pelaku sejarah pada masanya itu melaksanakan proses pendidikan. Pada masa kemunduran Islam abad 13-18, segala warisan filsafat dan ilmu pengetahuan diperoleh Eropa dari Islam, ketika umat Islam larut dalam kegemilangan sehingga tidak memperhatikan lagi pendidikan, maka Eropa tampil mencuri ilmu pengetahuan dan belajar dari Islam. Secara berangsur-angsur tetapi pasti, kekuasaan umat Islam ditundukkan oleh kekuasaan bangsa eropa dan terjadilah penjajahan dimana-mana di seluruh wilayah yang pernah dikuasai oleh kekuasaan Islam.

Sedangkan lembaga pendidikan ketiga muncul setelah kerajaan bani Umayyah. Materi yang diajarkan pada dar al Arqom ini adalah pokok-pokok ajaran Islam dan hukum-hukum. Al Suffah ini juga dijadikan sebagai asrama bagi mereka yang belum memiliki tempat tinggal yang kemudian dinamakan Ahl al Suffah. Dirumah-rumah inilah digunakan untuk kegiatan ilmiah, baik berdiskusi, tukar fikiran informasi, belajar membaca dan menulis, belajar pokok pokok keagamaan dan lain sebagainya.

Materi pendidikan, materi pendidikan ini muncul setelah adanya tujuan yang jelas. Lembaga pendidikan dan sistem pembelajaran masa Rasulullah (fase Mekkah) adalah rumah Arqam bin Abi Al-Arqam dan kuttab. Misalnya saja peradaban Arab pra Islam sering pula dikenal dengan nama Era Jahiliyyah (kebodohan). Hal tersebut merupakan salah satu alasan mengapa ilmu pengetahuan dan pendidikan itu sangat penting, karena melalui pendidikan seseorang akan mengetahui ilmu pengetahuan dengan baik dan menjadikan manusia seutuhnya dengan akal dan 
pikirannya. Rumah dan Suffah Berbicara lembaga pendidikan Islam, bermula pendidikan di Makkah oleh Rasullah yang pada saat itu masih sangat sederhana sekali yaitu tempat pertama yang digunakan Rasulullah untuk proses pembelajaran para sahabat yaitu di rumah sahabat Arqom yang kemudian dikenal dengan Dar al Arqom sebagai lembaga pendidikan Islam pertama.

Masjid yang semula dijadikan tempat belajar utama kini beralih menjadi tempat belajar orang dewasa sementara anak-anak mulai mempelajari ilmu di Kuttab. Hal tersebut sesuai dengan aspek pendidikan, dimana pendidikan sebagai tempat untuk mengangkat derajat manusia melalui ilmu pengetahuan dengan menerapkan berbagai macam cara dan metode. Kondisi masyarakat kala itu bukan hanya jahiliyyah, namun juga barbarisme dan cenderung primitive.

Pada masa Abbasiyah dianta rumah yang sering digunakan kegiatan ilmiah adalah rumah al rais Ibnu Sina, rumah Abu Sulaiman, rumah Imam Al Ghazali $(504 \mathrm{H})$, rumah Ya'qub bin Kalas wazir al aziz billah al fathimiy, rumah al sulfiy Ahmad bin Muhammad Abu Thahir (576H). Dasar pembelajarannya suffah ialah mengenai pokok-pokok ilmu agama serta baca tulis alQur'an. Selanjutnya, lembaga al Suffah merupakan suatu bangunan yang bersambung dengan masjid yang digunakan untuk proses pembelajaran secara rutin dan sistematik.

Terjadinya era globalisasi memberi dampak ganda, dampak yang menguntungkan dan dampak yang merugikan. Masingmasing menampilkan keunggulan yang dimiliki. Sedangkan globalisasi ialah pengglobalan secara keseluruhan aspek kehidupan, perwujudan (peningkatan/ perubahan) secara menyeluruh disegala aspek kehidupan. Karakteristik Era Globalisasi Era globalisasi akan ditandai dengan persaingan ekonomi secara hebat berbarengan dengan terjadinya revolusi teknologi informasi, teknologi komunikasi, dan teknologi industri.

Globalisasi sebagai sebuah proses mempunyai sejarah yang panjang. Kemudian berusaha mendominasi dunia dengan kekuatan teknologi, ilmu pengetahuan, politik, budaya, militer dan ekonomi. 
Pengertian Era Globalisasi Menurut bahasa, global ialah seluruhnya, menyeluruh. Dampak yang menguntungkan adalah memberi kesempatan kerjasama yang seluas-luasnya kepada negaranegara asing. Hal ini dapat disimpulkan bahwa yang dimaksud dengan era globalisasi adalah pertumbuhan di Negaranegara yang meliputi berbagai aspek kehidupan yang tidak dibatasi oleh adanya ruang dan waktu.

Menurut Robert Jackson dan Geog Sorensen, globalisasi adalah meluas dan meningkatnya hubungan ekonomi, sosial dan budaya yang melewati batas-batas internasional. Kemudian membaca pengertian secara luas globalisasi adalah proses pertumbuhan negara-negara maju (Amerika, Eropa dan Jepang) melakukan ekspansi besar-besaran. Tetapi di sisi lain, jika kita tidak mampu bersaing dengan mereka, karena sumber daya manusia (SDM) yang lemah, maka konsekuensinya akan merugikan bangsa kita.

Selain ketiganya, belakangan muncul Cina sebagai kekuatan baru ekonomi dunia dengan pertumbuhan ekonominya di atas 9 persen suatu jumlah tertinggi di dunia. Pendidikan Islam sebagai lembaga diakuinya keberadaan lembaga pendidikan Islam secara Eksplisit,Amerika misalnya unggul dalam produk teknologi, yaitu teknologi yang menghasilkan barang-barang baru dengan tingkat teknologi yang tinggi, contoh pembuatan pesawat terbang supersonik,robot,dan lain-lain. 